University of Nebraska - Lincoln

DigitalCommons@University of Nebraska - Lincoln

Agronomy \& Horticulture -- Faculty Publications

Agronomy and Horticulture Department

1994

\title{
Rotation and Nitrogen Fertilization Effects on Changes in Soil Carbon and Nitrogen
}

Gary E. Varvel

University of Nebraska-Lincoln, gevarvel@windstream.net

Follow this and additional works at: https://digitalcommons.unl.edu/agronomyfacpub

Part of the Plant Sciences Commons

Varvel, Gary E., "Rotation and Nitrogen Fertilization Effects on Changes in Soil Carbon and Nitrogen" (1994). Agronomy \& Horticulture -- Faculty Publications. 323.

https://digitalcommons.unl.edu/agronomyfacpub/323

This Article is brought to you for free and open access by the Agronomy and Horticulture Department at DigitalCommons@University of Nebraska - Lincoln. It has been accepted for inclusion in Agronomy \& Horticulture -Faculty Publications by an authorized administrator of DigitalCommons@University of Nebraska - Lincoln. 


\title{
Rotation and Nitrogen Fertilization Effects on Changes in Soil Carbon and Nitrogen
}

\author{
Gary E. Varvel*
}

\begin{abstract}
Long-term effects of cropping systems on soil properties, such as organic soil $\mathrm{C}$ and $\mathrm{N}$ levels, is necessary so more accurate projections can be made regarding the sequester and emission of $\mathrm{CO}_{2}$ by agricultural soils. This information can then be used to predict the effects of cropping systems on both soil degradation, maintenance, or improvement and global climate changes. My objective was to evaluate the effects of crop rotation and $\mathbf{N}$ fertilizer management on changes in total soil $\mathbf{C}$ and $\mathrm{N}$ concentrations that have occurred during an 8-yr period in a long-term study in the Western Corn Belt. Seven cropping systems (three monoculture, two 2-yr, and two 4-yr rotations) with three rates of $\mathrm{N}$ fertilizer were compared. Monocultures included continuous corn (Zea mays L.), soybean [Glycine max (L.) Merr.], and grain sorghum [Sorghum bicolor (L.) Moench]. The 2-yr rotations were corn-soybean and grain sorghum-soybean, and the two 4-yr rotations were corn-oat ( $A v$ ena sativa $\mathrm{L})$.+ clover (80\% Melilotus officinalis Lam. and $20 \%$ Trifolium pratense), grain sorghum-soybean and corn-soybean-grain sorghum-oat + clover. Soil samples were taken in the spring both in 1984 and 1992 to a depth of $30 \mathrm{~cm}$ in $0-$ to $7.5-\mathrm{cm}, 7.5-$ to $15-\mathrm{cm}$, and $15-$ to $30-\mathrm{cm}$ increments. No differences were obtained in 1984, but both rotation and $\mathrm{N}$ rate significantly affected total soil $\mathrm{C}$ and $\mathrm{N}$ concentrations in 1992. The results indicate that $C$ could be sequestered at 10 to $20 \mathrm{~g}$ $\mathrm{m}^{-2} \mathrm{yr}^{-1}$ in some cropping systems with sufficient levels of $\mathrm{N}$ fertilizer. Greater storage of $\mathrm{C}$ in soils suggests $\mathrm{CO}_{2}$ emissions from agricultural soils could be decreased with improved management practices and may in the long term have a significant effect on $\mathrm{CO}_{2}$ in the atmosphere under current climate conditions.
\end{abstract}

L ONG-TERM EFFECTS of management practices on soil properties provide information necessary to evaluate sustainability of cropping and tillage systems and their effect on the environment. Since soils can serve as both a source and a sink for atmospheric $\mathrm{CO}_{2}$, soil and crop management can affect the global balance of this greenhouse gas (CAST, 1992). Recent estimates (USEPA, 1991) indicate that, for U.S. agriculture, the current mix of tillage practices used in 1990 produced an emission rate of $8 \mathrm{Mt} \mathrm{CO}$ each year from soil organic C. Determination of long-term effects of cropping systems on soil properties, such as organic soil $\mathrm{C}$ and $\mathrm{N}$ levels, is necessary so accurate projections can be made regarding the sequester and emission of $\mathrm{CO}_{2}$ by agricultural soils. This information can then be used to predict the effects of cropping and tillage systems on both soil degradation, maintenance, or improvement and global climate changes.

Soil organic matter content is also considered an indicator of soil health. The significance of organic matter content and its effect on long-term sustainability has been documented many times and Doran and Parkin (1994) have included it as a major component of a required minimum data set in their definition of soil quality. Soils have various levels of quality, which are basically defined by stable natural or inherent features related to soil forming factors,

G.E. Varvel, USDA-ARS and Dep. of Agronomy, Univ. of Nebraska, Lincoln, NE 68583. Joint contribution of USDA-ARS and the Nebr. Agric. Res. Div., Joumal Series no. 10495. Received 26 May 1993. *Corresponding author.

Published in Agron. J. 86:319-325 (1994). and the loss of soil organic matter generally results in a reduction in soil quality.

Past history and research has documented organic matter degradation after soils were tilled (Dalal and Mayer, 1986; Haas et al., 1957; Johnston, 1986; Odell et al., 1984; Tiessen et al., 1982). Reduced tillage, an obvious alternative, has been shown to reduce the rate of organic matter degradation (Bauer and Black, 1981; Blevins et al., 1983; Gallaher and Ferrer, 1987; Lamb et al., 1985). At the same time, several researchers have shown increases in organic matter content, especially in no-tillage systems, as larger amounts of residue associated with increased yields are returned to the soil (Havlin et al., 1990; Larson et al., 1978; Rasmussen et al., 1980).

Crop rotations usually increase soil organic matter content, when compared with monocultures (Dick et al., 1986a,b; Johnston, 1986; Hargrove and Frye, 1987; Havlin et al., 1990; Odell et al., 1984). Nitrogen fertilizer has also been shown to increase organic matter content (Blevins et al., 1983; Power and Legg, 1978; Stevenson, 1986; Tate, 1987), but mostly in monoculture systems.

The need for information on the long-term effects of current agricultural practices were the basis for this study. Our objective was to evaluate the effects of crop rotation and $\mathrm{N}$ fertilizer management on changes in total soil $\mathrm{C}$ and $\mathrm{N}$ concentrations that occurred during $8 \mathrm{yr}$ in a longterm study in the western Corn Belt.

\section{MATERIALS AND METHODS}

The experiment was conducted on the Agronomy Farm at the University of Nebraska Agricultural Research and Development Center near Mead, NE, on a Sharpsburg silty clay loam (fine, montmorillonitic, mesic Typic Argiudoll). The study was comprised of seven cropping systems (three monoculture, two 2-yr, and two 4-yr rotations) with three rates of $\mathrm{N}$ fertilizer. Monocultures compared included continuous corn, continuous soybean, and continuous grain sorghum. Two-year rotations in the study were corn-soybean and grain sorghum-soybean; the two 4-yr rotations were corn-oat + clover-grain sorghum-soybean and corn-soybean-grain sorghum-oat +clover. Each phase of every rotation occurred every year, for a total of 15 rotation treatments per replication. Treatments were assigned to experimental units ( 9 by $32 \mathrm{~m}$ ) in factorial combinations of rotation and crop within rotation in four randomized complete blocks in 1982 and no fertilizer $\mathrm{N}$ was applied to any of the monoculture or rotation plots that cropping season.

Three subplots ( 9 . by $10 \mathrm{~m}$ ), separated by $1-\mathrm{m}$ alleys, were randomly assigned a 0 , low, or high $\mathrm{N}$ rate within each wholeplot treatment, starting with the 1983 cropping season. Nitrogen rates were to 0,90 , or $180 \mathrm{~kg} \mathrm{ha}^{-1}$ for corn and grain sorghum and 0,34 , or $68 \mathrm{~kg} \mathrm{ha}^{-1}$ for soybean and oat+clover crops. Nitrogen was sidedressed as liquid urea-ammonium nitrate solution (32-0-0) in 1983 and 1984, and has been broadcast as granular ammonium nitrate (34-0-0) in succeeding years. Oat + clover plots were fertilized in early May by broadcasting granular ammonium nitrate throughout the study. Nitrogen applications were made in early- to mid-June for corn, grain sorghum, and soybean.

Cultural practices were similar to those used by local pro- 
ducers. Previous crop residue from corn or grain sorghum was shredded in late fall with a rotary mower. Clover from the previous oat + clover plots was killed with a tandem disk in midApril when weather permitted. Spring tillage usually consisted of disking once or twice 10 to $15 \mathrm{~cm}$ deep and then harrowing just prior to planting.

Oat was seeded as early as possible in the spring in $18 \mathrm{~cm}$ rows at a rate of $100 \mathrm{~kg}$ seed ha ${ }^{-1}$. Rhizobium-inoculated clover was seeded at $18 \mathrm{~kg} \mathrm{ha}^{-1}$ in the same operation. A corn hybrid adapted to eastern Nebraska was planted with a six-row planter in $76-\mathrm{cm}$ rows at a rate of 47000 viable seeds ha ${ }^{-1}$ during the first 2 wk of May in all years. Soybean and grain sorghum were seeded in 76-cm rows at rates of 370000 and 173000 seeds ha $\mathrm{h}^{-1}$, respectively. Soybean plots were field cultivated and harrowed just prior to seeding in addition to being disked. Weed control was accomplished using combinations of broad spectrum herbicides in preemergence applications. Herbicides were selected for each rotation to obtain optimum weed control and to reduce carryover problems for successive crops in that rotation.

Dry matter samples for oat were collected at physiological maturity (late June) by harvesting three rows, $5 \mathrm{~m}$ in length. These samples were weighed and dried for dry matter yield determinations before being threshed to separate grain and straw using a stationary plot thresher.

Aboveground dry matter samples ( 1 row by $5 \mathrm{~m}$ ) for corn were also collected each year soon after physiological maturity. Ears were removed, stalks were cut at ground level, and samples were weighed separately. A stover subsample (five representative plants) was chopped, weighed, and dried for dry matter yield determination.

Dry matter samples ( 1 row by $5 \mathrm{~m}$ ) were also collected each year for both soybean and grain sorghum at physiological maturity. Soybean samples were weighed and dried for dry matter yield determination before being threshed using a stationary plot thresher. Grain sorghum whole plant samples were weighed; heads were removed from the plants and were dried, weighed, and threshed; and five representative plants were chopped, weighed, and dried for dry matter yield determination.

Soil samples were taken in the spring of 1984 from rotation plots, to establish base or beginning concentrations for soil $\mathrm{C}$ and $\mathrm{N}$ in each of the cropping systems. Fifteen cores $(1.8 \mathrm{~cm}$ diam.) were taken to a depth of $30 \mathrm{~cm}$ from each whole-plot treatment. Each of these cores was divided into $0-$ to $7.5-\mathrm{cm}$, $7.5-$ to $15-\mathrm{cm}$, and $15-$ to $30-\mathrm{cm}$ depth increments, and all 15 cores were composited by depth.

Soil samples were then taken on a yearly basis in the spring prior to planting, to evaluate the effects of rotations, crops in rotation, and $\mathrm{N}$ rates. Fifteen cores $(1.8 \mathrm{~cm}$ diam.) were again taken to a depth of $30 \mathrm{~cm}$, but this time separate samples were taken from each $\mathrm{N}$ rate subplot within the whole-plot treatments. These samples were divided into the same depth increments as described above and were again composited by depth.

All samples were air dried and then ground. For the purposes of this paper, only results from the analyses of the initial samples (1984) and those taken in the spring of 1992 will be considered. Each of these samples was analyzed for total $\mathrm{C}$ and $\mathrm{N}$ using an automatic $\mathrm{C}$ and $\mathrm{N}$ analyzer interfaced with a continuousflow mass spectrometer for purposes of routine analyses according to the procedure described by Schepers et al. (1989). All values reported for total $\mathrm{C}$ and $\mathrm{N}$ concentrations are expressed on a gravimetric basis. Soil bulk density measurements were not determined at either of these sampling times, but measurements taken at three separate sampling times had indicated no differences in bulk density between cropping systems at any of these depths (unpublished data).

Results from the total $\mathrm{C}$ and $\mathrm{N}$ analyses were analyzed separately in 1984 and 1992 . Changes in total soil $C$ and $N$ con- centrations between 1984 and 1992 were then analyzed to determine rotation and $\mathrm{N}$ fertilization effects. Since only wholeplot samples were taken in 1984, 1992 results were partitioned by fertilizer $\mathrm{N}$ rate. Differences in total soil $\mathrm{C}$ and $\mathrm{N}$ concentrations were determined between each fertilizer $N$ rate (1992) and the initial levels (1984) to determine rotation effects at all three $\mathrm{N}$ rates. Results were analyzed by depth to determine changes in total soil $\mathrm{C}$ and $\mathrm{N}$ concentrations in the surface 30 $\mathrm{cm}$. Orthogonal comparisons were used to partition rotation sums of squares to directly evaluate objectives (Steel and Torrie, 1980). All statistical analyses were performed using the Statistical Analysis System (SAS Institute, 1992).

\section{RESULTS}

Soil samples taken at the beginning of the test showed cropping system had no effect on total $\mathrm{C}$ or $\mathrm{N}$ concentrations at any depth (Table 1). Total $\mathrm{C}$ concentrations for the entire study in 1984 averaged $16.9 \mathrm{~g} \mathrm{~kg}^{-1}$ at the 0 -to $7.5-\mathrm{cm}$ depth, $14.7 \mathrm{~g} \mathrm{~kg}^{-1}$ at the $7.5-$ to $15-\mathrm{cm}$ depth, and $12.0 \mathrm{~g} \mathrm{~kg}^{-1}$ at the $15-$ to $30-\mathrm{cm}$ depth. Similarly, total $\mathrm{N}$ concentrations averaged $1.6 \mathrm{~g} \mathrm{~kg}^{-1}$ at the $0-$ to $7.5-\mathrm{cm}$ depth, $1.4 \mathrm{~g} \mathrm{~kg}^{-1}$ at the $7.5-$ to $15-\mathrm{cm}$ depth, and $1.2 \mathrm{~g}$ $\mathrm{kg}^{-1}$ at the $15-$ to $30-\mathrm{cm}$ depth.

Treatment had no effect on soil bulk density, which averaged $1.2,1.35$, and $1.25 \mathrm{Mg} \mathrm{m}^{-3}$ for the $0-$ to $7.5-\mathrm{cm}$, 7.5- to $15-\mathrm{cm}$, and $15-$ to $30-\mathrm{cm}$ depths, respectively (unpublished data). As noted in the Materials and Methods section, these samples were collected at other times. The slightly greater bulk density for the $7.5-$ to $15-\mathrm{cm}$ depth was probably due to the use of the disk as the primary tillage implement over the duration of the study.

Total soil $\mathrm{C}$ and $\mathrm{N}$ concentrations presented in Table 2 reflect effects of cropping system and $\mathrm{N}$ fertilization after 8 yr. This time period represents two cycles of the 4-yr rotations, four cycles of the 2-yr rotations, and $8 \mathrm{yr}$ of the monocultures. Rotations and $\mathrm{N}$ rates affected total soil $\mathrm{C}$ and $\mathrm{N}$ concentrations in the surface 0 - to $7.5-\mathrm{cm}$ depth during this period (Table 2). Specifically, contrasts indicated significant differences between total soil $\mathrm{C}$ and $\mathrm{N}$ concentrations in the 2-yr and 4-yr rotations and among 4 -yr rotations in the surface samples. Total soil $\mathrm{C}$ and $\mathrm{N}$ concentrations ( 0 - to $7.5-\mathrm{cm}$ depth) for 1992 averaged 16.6 and $1.59 \mathrm{~g} \mathrm{~kg}^{-1}$ in 2-yr rotations and 18.2 and $1.72 \mathrm{~g} \mathrm{~kg}^{-1}$ in 4-yr rotations.

Nitrogen fertilizer rate also affected total soil $\mathrm{C}$ and $\mathrm{N}$ concentrations during the first $8 \mathrm{yr}$ of the study (Table 2). Total soil $C$ concentrations (0- to $7.5-\mathrm{cm}$ depth) for 1992 averaged $16.9,17.3$, and $17.7 \mathrm{~g} \mathrm{~kg}^{-1}$ and soil $\mathrm{N}$ concentrations averaged $1.60,1.65$, and $1.68 \mathrm{~g} \mathrm{~kg}^{-1}$ for 0 , low, and high fertilizer $\mathrm{N}$ rates, respectively. These results demonstrated greater increases in total $\mathrm{C}$ and $\mathrm{N}$ concentrations were obtained with increased $\mathrm{N}$ fertilizer rate than those reported by Blevins et al. (1983) and Havlin et al. (1990).

Analyses of the effects of these cropping systems and $\mathrm{N}$ rates on changes in total soil $\mathrm{C}$ and $\mathrm{N}$ concentrations after 8 yr provide a measure of soil degradation, maintenance, or improvement that has occurred as a result of the different management practices in the study.

Changes in total soil $\mathrm{C}$ and $\mathrm{N}$ concentrations shown in Table 3 demonstrate the effects of cropping systems with- 
VARVEL: SOIL EFFECTS OF ROTATION AND NITROGEN FERTILIZATION

Table 1. Total soil $\mathrm{C}$ and $\mathrm{N}$ concentrations in each rotation at the $0-$ to $7.5-\mathrm{cm}, 7.5-$ to $15-\mathrm{cm}$, and $15-$ to $30-\mathrm{cm}$ depths in 1984 at $\mathrm{Mead}$, $\mathrm{NE}$.

\begin{tabular}{|c|c|c|c|c|c|c|c|}
\hline \multirow[b]{2}{*}{ Rotation† } & & \multicolumn{3}{|c|}{ Carbon } & \multicolumn{3}{|c|}{ Nitrogen } \\
\hline & & $0-7.5 \ddagger$ & $7.5-15$ & $15-30$ & $0-7.5 \ddagger$ & $7.5-15$ & $15-30$ \\
\hline & & & & & & & \\
\hline \multicolumn{2}{|l|}{$\begin{array}{l}\mathrm{CC} \\
\mathrm{CSB}\end{array}$} & 17.2 & 14.3 & 11.0 & 1.6 & 1.4 & 1.1 \\
\hline \multicolumn{2}{|l|}{ CSB } & 16.8 & 15.3 & 13.2 & 1.6 & 1.4 & 1.3 \\
\hline \multicolumn{2}{|l|}{$\begin{array}{l}\text { CSG } \\
\text { C-SB }\end{array}$} & 16.6 & 14.7 & 12.3 & 1.6 & 1.4 & 1.2 \\
\hline \multicolumn{2}{|l|}{ C-SB } & 16.4 & 14.6 & 12.3 & 1.5 & 1.4 & 1.2 \\
\hline \multirow{2}{*}{\multicolumn{2}{|c|}{$\begin{array}{l}\text { SG-SB } \\
\text { C-OCL-SG-SB }\end{array}$}} & 16.2 & 14.2 & 10.6 & 1.6 & 1.4 & 1.1 \\
\hline & & 17.6 & 15.2 & 12.7 & 1.6 & 1.4 & 1.2 \\
\hline \multirow{2}{*}{\multicolumn{2}{|c|}{$\begin{array}{l}\text { C-SB-SG-OCL } \\
\text { CV }, \%\end{array}$}} & 16.7 & 14.5 & 11.7 & 1.6 & 1.4 & 1.2 \\
\hline & & 9.2 & 10.7 & 24.8 & 6.7 & 7.5 & 19.3 \\
\hline \multicolumn{8}{|l|}{ Source of variation } \\
\hline $\begin{array}{l}\text { Replication } \\
\text { Rotation }\end{array}$ & 3 & $20.4^{* *}$ & $26.6^{* *}$ & 24.0 & $0.13^{* *}$ & $0.18^{* *}$ & $0.20^{*}$ \\
\hline \multirow{2}{*}{$\begin{array}{l}\text { Rotation } \\
\text { Continuous vs. rotation } \$\end{array}$} & 6 & 2.6 & 1.4 & 6.0 & 0.01 & 0.01 & 0.03 \\
\hline & 1 & 0.2 & 0.1 & 1.1 & 0.01 & 0.00 & 0.01 \\
\hline CC \& CSG vs. CSB & 1 & 0.0 & 1.8 & 6.8 & 0.00 & 0.00 & 0.06 \\
\hline \multirow{2}{*}{$\begin{array}{l}\text { 2-yr vs. 4-yr rotation } \\
\text { Among 2-yr rotations }\end{array}$} & 1 & 7.8 & 2.3 & 5.8 & 0.05 & 0.03 & 0.03 \\
\hline & 1 & 0.1 & 0.7 & 11.6 & 0.00 & 0.00 & 0.03 \\
\hline \multirow{2}{*}{$\begin{array}{l}\text { Among 4-yr rotations } \\
\text { Error }\end{array}$} & 1 & 6.9 & 3.3 & 8.1 & 0.01 & 0.00 & 0.02 \\
\hline & 50 & 2.4 & 2.5 & 8.9 & 0.01 & 0.01 & 0.05 \\
\hline
\end{tabular}

*,** Significant at the 0.05 and 0.01 probability levels, respectively.

$+\mathrm{CC}=$ continuous corn, $\mathrm{CSB}=$ continuous soybean, $\mathrm{CSG}=$ continuous grain sorghum, $\mathrm{C}-\mathrm{SB}=$ corn-soybean, $\mathrm{SG}-\mathrm{SB}=$ grain sorghum-soybean, $\mathrm{C}-\mathrm{OCL}-\mathrm{SG}-\mathrm{SB}$ $=$ corn-oat + clover-grain sorghum-soybean, C-SB-SG-OCL = corn-soybean-grain sorghum-oat + clover .

$¥$ Depth, cm.

$\S$ Contrasts.

out $\mathrm{N}$ fertilizer additions. Total soil $\mathrm{C}$ and $\mathrm{N}$ concentrations for the $0-$ to $7.5-\mathrm{cm}$ depth have both been significantly affected by rotation (Table 3 ). Contrasts indicate that differences occurred between the continuous cropping and rotation systems and between 2-yr and 4-yr rotations and among 4-yr rotations. Generally, total soil $\mathrm{C}$ and $\mathrm{N}$ concentrations have decreased for continuous cropping, while rotations have maintained or even increased total soil $\mathrm{C}$ and $\mathrm{N}$ concentrations in the surface layer. Differences between 2-yr and 4-yr rotations were significant, because changes in total soil $\mathrm{C}$ and $\mathrm{N}$ concentrations were much greater in the 4-yr than in the 2-yr rotations.

Analyses of changes in total soil $\mathrm{C}$ and $\mathrm{N}$ concentrations at the low $\mathrm{N}$ fertilizer rate in all systems are shown in Table 4. At this $\mathrm{N}$ fertilizer rate, significant changes in total soil $\mathrm{C}$ and $\mathrm{N}$ concentrations at the $0-$ to $7.5-\mathrm{cm}$ depth were measured between 2-yr and 4-yr rotations. Changes in total soil $\mathrm{N}$ concentration between continuous corn and grain sorghum and continuous soybean were also significant. In general, results at this $\mathrm{N}$ level were similar to those without fertilizer $\mathrm{N}$ applied, except the results at the low $\mathrm{N}$ level tended to indicate that with rotations, total soil $\mathrm{C}$ and $\mathrm{N}$ concentrations have been maintained or increased above those at the beginning of the study.

Analyses of changes in total soil $\mathrm{C}$ and $\mathrm{N}$ concentrations at the high $\mathrm{N}$ fertilizer rate in all systems are shown in Table 5. Similar to the lower $\mathrm{N}$ rates, changes in total soil $\mathrm{C}$ and $\mathrm{N}$ concentrations were only obtained at the $0-$ to 7.5-cm depth. At the highest $\mathrm{N}$ fertilizer rate, total soil $\mathrm{C}$ and $\mathrm{N}$ concentrations were significantly increased in almost every cropping system. Exceptions occurred with continuous soybean and the corn-soybean 2-yr rotation for total soil $\mathrm{C}$ and $\mathrm{N}$ concentrations and with the grain sorghum-soybean 2-yr rotation for total soil $\mathrm{N}$ concentration. In these cases, changes in total soil $\mathrm{C}$ and $\mathrm{N}$ concentrations were minimal over the $8 \mathrm{yr}$ of the study.

\section{DISCUSSION}

Several studies on changes in soil organic matter content over time (Dick et al., 1986a,b; Havlin et al., 1990) have included crop rotations, but emphasis has been on comparisons between no-tillage and conventional tillage systems. As expected in such experiments, most of the significant changes in total soil $\mathrm{C}$ and $\mathrm{N}$ concentrations have occurred between no-tillage and conventional tillage systems. We show that crop rotation can have a significant effect on $\mathrm{C}$ and $\mathrm{N}$ concentrations with conventional tillage.

Significant differences in total soil $\mathrm{C}$ and $\mathrm{N}$ concentrations have been reported between certain rotations, but most of these have been attributed to the increased production in these systems, which resulted in greater amounts of residue returned to the soil. Our study produced similar results for the continuous corn and grain sorghum systems receiving the highest $\mathrm{N}$ fertilizer rate. The amount of residue being returned to the soil from 1984 through 1992 in these two cropping systems at the highest $\mathrm{N}$ rate averaged 6.2 and $6.9 \mathrm{Mg} \mathrm{ha}^{-1} \mathrm{yr}^{-1}$ for continuous corn and continuous grain sorghum, respectively (unpublished data). At these residue levels, total soil $\mathrm{C}$ concentrations in the 0 - to $7.5-\mathrm{cm}$ depth increased $0.75 \mathrm{~g} \mathrm{~kg}^{-1}$ in continuous corn and $1.63 \mathrm{~g} \mathrm{~kg}^{-1}$ in continuous grain sorghum during the 8-yr period. These results agree very closely with those of Larson et al. (1972), where similar rates of corn residue had been added to the soil in a continuous corn system.

Significant differences in total soil $\mathrm{C}$ and $\mathrm{N}$ changes in the 0 - to $7.5-\mathrm{cm}$ depth with the highest $\mathrm{N}$ fertilizer rate are very intriguing, especially between continuous corn or grain sorghum, and continuous soybean and between 2-yr and 4-yr rotations (Table 5). The differences between continuous corn or grain sorghum and continuous soybean systems are not surprising, because the amount of residue returned to the soil with continuous soybean has averaged 
Table 2. Total soil $\mathrm{C}$ and $\mathrm{N}$ concentrations as affected by rotation and $\mathrm{N}$ rate at the $0-$ to $7.5-\mathrm{cm}, 7.5-$ to $15-\mathrm{cm}$, and $15-$ to $30-\mathrm{cm}$ depths in 1992 at Mead, NE.

\begin{tabular}{|c|c|c|c|c|c|c|c|}
\hline \multirow[b]{2}{*}{ Rotation $\dagger$} & \multirow[b]{2}{*}{$\mathbf{N}$ rate } & \multicolumn{3}{|c|}{ Carbon } & \multicolumn{3}{|c|}{ Nitrogen } \\
\hline & & $0-7.5 \ddagger$ & $7.5-15$ & $15-30$ & $0-7.5 \ddagger$ & $7.5-15$ & $15-30$ \\
\hline \multirow[b]{2}{*}{$\mathrm{CC}$} & $\mathrm{kg} \mathrm{ha}^{-1}$ & & 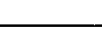 & 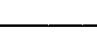 & $\longrightarrow$ & & \\
\hline & $\begin{array}{c}\text { 0 } \\
\text { Low } \\
\text { High }\end{array}$ & $\begin{array}{l}16.3 \\
17.4 \\
18.0\end{array}$ & $\begin{array}{l}14.5 \\
14.3 \\
15.0\end{array}$ & $\begin{array}{l}11.2 \\
11.0 \\
10.9\end{array}$ & $\begin{array}{l}1.56 \\
1.67 \\
1.72\end{array}$ & $\begin{array}{l}1.42 \\
1.42 \\
1.46\end{array}$ & $\begin{array}{l}1.14 \\
1.14 \\
1.11\end{array}$ \\
\hline CSB & $\begin{array}{c}0 \\
\text { Low } \\
\text { High }\end{array}$ & $\begin{array}{l}16.3 \\
16.8 \\
16.7\end{array}$ & $\begin{array}{l}14.9 \\
15.1 \\
15.1\end{array}$ & $\begin{array}{l}13.0 \\
12.9 \\
12.8\end{array}$ & $\begin{array}{l}1.56 \\
1.59 \\
1.59\end{array}$ & $\begin{array}{l}1.43 \\
1.45 \\
1.44\end{array}$ & $\begin{array}{l}1.25 \\
1.27 \\
1.25\end{array}$ \\
\hline CSG & $\begin{array}{c}0 \\
\text { Low } \\
\text { High }\end{array}$ & $\begin{array}{l}16.8 \\
17.8 \\
18.3\end{array}$ & $\begin{array}{l}14.8 \\
15.0 \\
14.7\end{array}$ & $\begin{array}{l}12.2 \\
11.6 \\
11.5\end{array}$ & $\begin{array}{l}1.57 \\
1.66 \\
1.71\end{array}$ & $\begin{array}{l}1.41 \\
1.44 \\
1.42\end{array}$ & $\begin{array}{l}1.19 \\
1.16 \\
1.17\end{array}$ \\
\hline C-SB & $\begin{array}{c}0 \\
\text { Low } \\
\text { High }\end{array}$ & $\begin{array}{l}16.4 \\
16.7 \\
16.6\end{array}$ & $\begin{array}{l}14.3 \\
14.6 \\
14.4\end{array}$ & $\begin{array}{l}12.5 \\
12.2 \\
11.9\end{array}$ & $\begin{array}{l}1.55 \\
1.58 \\
1.58\end{array}$ & $\begin{array}{l}1.38 \\
1.40 \\
1.40\end{array}$ & $\begin{array}{l}1.22 \\
1.19 \\
1.16\end{array}$ \\
\hline SG-SB & $\begin{array}{c}0 \\
\text { Low } \\
\text { High }\end{array}$ & $\begin{array}{l}16.5 \\
16.5 \\
17.1\end{array}$ & $\begin{array}{l}14.3 \\
14.1 \\
14.3\end{array}$ & $\begin{array}{l}10.5 \\
10.6 \\
10.7\end{array}$ & $\begin{array}{l}1.59 \\
1.61 \\
1.64\end{array}$ & $\begin{array}{l}1.40 \\
1.38 \\
1.40\end{array}$ & $\begin{array}{l}1.08 \\
1.08 \\
1.10\end{array}$ \\
\hline C-OCL-SG-SB & $\begin{array}{c}0 \\
\text { Low } \\
\text { High }\end{array}$ & $\begin{array}{l}18.5 \\
18.5 \\
19.0\end{array}$ & $\begin{array}{l}15.3 \\
15.1 \\
15.4\end{array}$ & $\begin{array}{l}12.9 \\
12.4 \\
12.4\end{array}$ & $\begin{array}{l}1.73 \\
1.74 \\
1.79\end{array}$ & $\begin{array}{l}1.45 \\
1.44 \\
1.46\end{array}$ & $\begin{array}{l}1.24 \\
1.23 \\
1.22\end{array}$ \\
\hline C--SB-SG-OCL & $\begin{array}{c}0 \\
\text { Low } \\
\text { High }\end{array}$ & $\begin{array}{l}17.5 \\
17.8 \\
18.1\end{array}$ & $\begin{array}{l}14.3 \\
14.5 \\
14.5\end{array}$ & $\begin{array}{l}11.2 \\
11.4 \\
11.6\end{array}$ & $\begin{array}{l}1.65 \\
1.69 \\
1.72\end{array}$ & $\begin{array}{l}1.38 \\
1.39 \\
1.40\end{array}$ & $\begin{array}{l}1.11 \\
1.13 \\
1.14\end{array}$ \\
\hline $\mathrm{CV}, \%$ & 7.3 & 10.1 & 21.9 & 5.0 & 7.0 & & 16.6 \\
\hline Source of variation & $\underline{\mathrm{df}}$ & \multicolumn{6}{|c|}{ mean squares } \\
\hline Replication & 3 & $34.3^{* *}$ & $53.1^{* *}$ & $66.8^{* *}$ & $0.11^{* *}$ & $0.21 * *$ & $0.38 * *$ \\
\hline Rotation & 6 & $19.2^{*}$ & 4.2 & 15.6 & $0.13^{* *}$ & 0.02 & 0.09 \\
\hline Continuous vs. rotation $\S$ & 1 & 2.3 & 1.5 & 1.2 & 0.03 & 0.02 & 0.02 \\
\hline CC \& CSG vs. CSB & 1 & 5.1 & 0.7 & 18.4 & $0.04^{*}$ & 0.00 & 0.09 \\
\hline 2-yr vs. 4-yr rotation & 1 & $83.0^{* *}$ & 8.2 & 11.7 & $0.54 * *$ & 0.03 & 0.06 \\
\hline Among 2 -yr rotations & 1 & 0.3 & 0.4 & $29.6^{*}$ & 0.02 & 0.00 & $0.13^{*}$ \\
\hline Among 4-yr rotations & 1 & $17.0^{* *}$ & $15.0^{* *}$ & $30.3^{*}$ & $0.12^{* *}$ & $0.10^{* *}$ & $0.26^{* *}$ \\
\hline Error $a$ & 18 & 5.8 & 8.1 & 21.2 & 0.02 & 0.03 & 0.11 \\
\hline $\mathrm{N}$ rate & 2 & $6.2^{*}$ & 0.3 & 0.7 & $0.06^{* *}$ & 0.00 & 0.00 \\
\hline 0 N vs. others§ & $\overline{1}$ & $10.2^{* *}$ & 0.3 & 1.3 & $0.11^{* *}$ & 0.00 & 0.00 \\
\hline Rotation $\times \mathrm{N}$ rate & 12 & 0.5 & 0.2 & 0.5 & 0.00 & 0.00 & 0.00 \\
\hline Error $b$ & 138 & 1.6 & 2.2 & 6.7 & 0.01 & 0.01 & 0.03 \\
\hline
\end{tabular}

*** Significant at the 0.05 and 0.01 probability levels, respectively.

$\dagger \mathrm{CC}=$ continuous corn, $\mathrm{CSB}=$ continuous soybean, $\mathrm{CSG}=$ continuous sorghum, $\mathrm{C}-\mathrm{SB}=$ corn-soybean, $\mathrm{SG}-\mathrm{SB}=$ grain sorghum-soybean, $\mathrm{C}-\mathrm{OCL}-\mathrm{SG}-\mathrm{SB}$ $=$ corn-oat + clover-grain sorghum-soybean, $\mathrm{C}-\mathrm{SB}-\mathrm{SG}-\mathrm{OCL}=$ corn-soybean-grain sorghum-oat + clover.

$\ddagger$ Depth, cm.

$\S$ Contrasts.

3.0 $\mathrm{Mg} \mathrm{ha}^{-1} \mathrm{yr}^{-1}$, less than half that returned for the other two crops. Havlin et al. (1990) also found that total soil $\mathrm{C}$ and $\mathrm{N}$ concentrations decreased with increasing frequency of soybean in the rotation.

A most interesting result was the significant difference in the amount of change in total soil $\mathrm{C}$ and $\mathrm{N}$ concentrations between 2-yr and 4-yr rotations (see contrast in Table 5). Total soil $\mathrm{C}$ and $\mathrm{N}$ concentrations were increased to a greater extent in the 4-yr rotations than the 2-yr rotations, even though the amount of crop residue returned has averaged only $0.6 \mathrm{Mg} \mathrm{ha}^{-1} \mathrm{yr}^{-1}$ more in the 4-yr rotations. These results also support the conclusion reached by Havlin et al. (1990), in that increased frequency of soybean in the rotation resulted in lower concentrations of soil $\mathrm{C}$ and $\mathrm{N}$.

In summary, results from this study are similar to those of others, in that we have shown a significant effect of rotation on total soil $\mathrm{C}$ and $\mathrm{N}$ concentrations. We have also shown that $\mathrm{N}$ fertilizer significantly increased both total soil $\mathrm{C}$ and $\mathrm{N}$ concentrations to a much greater extent than has been reported earlier. These results have also shown that both rotation and $\mathrm{N}$ fertilizer can significantly increase total soil $\mathrm{C}$ and $\mathrm{N}$ concentrations, even with conventional tillage systems, when selected crop rotations are used with adequate levels of management.

The cumulative amount of $\dot{C}$ and $\mathrm{N}$ sequestered or lost over the 8-yr period in each of the cropping systems for the 0 - to $15-\mathrm{cm}$ depth is shown in Table 6 . Results are based on the bulk density data reported earlier for the 0to $7.5-\mathrm{cm}$ and $7.5-$ to $15-\mathrm{cm}$ depths. The results for the 15- to $30-\mathrm{cm}$ depth have not been included in these calculations for two reasons: first, tillage or mechanical disturbance had not occurred at that depth in our study; and, second, results from this depth were greatly affected by the depth to subsoil. In actuality, most of the significant differences in total soil $\mathrm{C}$ and $\mathrm{N}$ concentrations occurred in the 0 - to $7.5-\mathrm{cm}$ depth, but because tillage is occurring on an annual basis to a greater depth than that, the total amount of $\mathrm{C}$ and $\mathrm{N}$ sequestered or lost to a depth of $15 \mathrm{~cm}$ is presented (Table 6). 
Table 3. Change in total soil $C$ and $N$ concentrations with no $N$ applied from 1984 to 1992 in each rotation at the $0-$ to $7.5-\mathrm{cm}, 7.5-$ to $15-\mathrm{cm}$, and 15- to 30-cm depths at Mead, NE.

\begin{tabular}{|c|c|c|c|c|c|c|c|}
\hline \multirow[b]{2}{*}{ Rotation $\dagger$} & & \multicolumn{3}{|c|}{$\Delta C \ddagger$} & \multicolumn{3}{|c|}{$\Delta \mathbf{N} \ddagger$} \\
\hline & & $0-7.58$ & $7.5-15$ & $15-30$ & $0-7.58$ & $7.5-15$ & $15-30$ \\
\hline & & & & & -1 & & \\
\hline \multirow{7}{*}{\multicolumn{2}{|c|}{$\begin{array}{l}\text { CC } \\
\text { CSB } \\
\text { CSG } \\
\text { C-SB } \\
\text { SG-SB } \\
\text { C-OCL-SG-SB } \\
\text { C-SB-SG-OCL }\end{array}$}} & -0.88 & 0.25 & 0.18 & -0.04 & 0.05 & 0.09 \\
\hline & & -0.50 & -0.40 & -0.25 & -0.07 & 0.00 & -0.03 \\
\hline & & 0.18 & 0.10 & -0.08 & -0.03 & 0.01 & -0.01 \\
\hline & & 0.04 & -0.31 & 0.19 & 0.02 & 0.00 & 0.06 \\
\hline & & 0.30 & 0.06 & -0.11 & 0.03 & 0.05 & 0.00 \\
\hline & & 0.88 & 0.08 & 0.17 & 0.10 & 0.03 & 0.05 \\
\hline & & 0.81 & -0.27 & -0.44 & 0.05 & -0.03 & 0.04 \\
\hline \multicolumn{8}{|l|}{ Source of variation } \\
\hline Replication & 3 & $4.88 * *$ & $5.41^{* *}$ & $2.77 *$ & $0.040^{* *}$ & $0.063 * *$ & $0.048^{\star *}$ \\
\hline Rotation & 6 & $2.89^{* *}$ & 0.43 & 0.68 & $0.024 * *$ & 0.008 & $0.019 *$ \\
\hline Continuous vs. rotation & 1 & $10.17^{* *}$ & 0.08 & 0.00 & $0.079^{* *}$ & 0.001 & 0.000 \\
\hline CC \& CSG vs. CSB & $\mathbf{1}$ & 0.06 & 0.88 & 0.24 & 0.003 & 0.002 & 0.012 \\
\hline 2-yr vs. 4-yr rotation & 1 & $4.82^{*}$ & 0.01 & 0.33 & $0.027^{*}$ & 0.008 & 0.006 \\
\hline Among 2-yr rotations & $\mathbf{1}$ & 0.28 & 0.56 & 0.36 & 0.001 & 0.008 & 0.013 \\
\hline Among 4-yr rotations & 1 & 0.04 & 0.98 & 3.00 & 0.019 & 0.026 & $0.067 * *$ \\
\hline Error & 50 & 0.75 & 0.39 & 0.87 & 0.005 & 0.006 & 0.006 \\
\hline
\end{tabular}

**" Significant at the 0.01 and 0.05 probability levels, respectively.

† CC = continuous com, CSB = continuous soybean, CSG = continuous grain sorghum, C-SB = com-soybean, SG-SB = grain sorghum-soybean, C-OCL-SG-SB = com-oat +clover-grain sorghum-soybean, C-SB-SG-OCL = corn-soybean-grain sorghum-oat +clover .

$\ddagger$ Change in $C$ and $N$ concentrations from 1984 to 1992.

8 Depth, cm.

Contrasts.

Table 4. Change in total soil $C$ and $N$ concentrations with a low rate of $N$ applied from 1984 to 1992 in each rotation at the 0 - to $7.5-\mathrm{cm}$, 7.5- to $15-\mathrm{cm}$, and 15- to $30-\mathrm{cm}$ depths at Mead, NE.

\begin{tabular}{|c|c|c|c|c|c|c|c|}
\hline \multirow[b]{2}{*}{ Rotation $\dagger$} & & \multicolumn{3}{|c|}{$\Delta \mathbf{C} \ddagger$} & \multicolumn{3}{|c|}{$\Delta \mathbf{N} \ddagger$} \\
\hline & & $0-7.58$ & $7.5-15$ & $15-30$ & $0-7.58$ & $7.5-15$ & $15-30$ \\
\hline $\begin{array}{l}\text { CC } \\
\text { CSB } \\
\text { CSG } \\
\text { C-SB } \\
\text { SG-SB } \\
\text { C-OCL-SG-SB } \\
\text { C-SB-SG-OCL }\end{array}$ & & $\begin{array}{l}0.15 \\
0.00 \\
1.13 \\
0.26 \\
0.34 \\
0.86 \\
1.13\end{array}$ & $\begin{array}{r}0.05 \\
-0.20 \\
0.30 \\
-0.05 \\
-0.08 \\
-0.13 \\
-0.01\end{array}$ & $\begin{array}{r}0.00 \\
-0.33 \\
-0.70 \\
-0.14 \\
-0.04 \\
-0.33 \\
-0.26\end{array}$ & $\begin{array}{r}0.07 \\
-0.03 \\
0.06 \\
0.04 \\
0.05 \\
0.10 \\
0.09\end{array}$ & $\begin{array}{r}0.05 \\
0.03 \\
0.04 \\
0.02 \\
0.03 \\
0.02 \\
-0.01\end{array}$ & $\begin{array}{r}0.09 \\
-0.01 \\
-0.04 \\
0.03 \\
0.00 \\
-0.03 \\
-0.02\end{array}$ \\
\hline Source of variation & $\underline{\mathrm{df}}$ & & & & uares & & \\
\hline $\begin{array}{l}\text { Replication } \\
\text { Rotation } \\
\text { Continuous vs. rotation } \\
\text { CC \& CSG vs. CSB } \\
\text { 2-yr vs. 4-yr rotation } \\
\text { Among 2-yr rotations } \\
\text { Among 4-yr rotations } \\
\text { Error }\end{array}$ & $\begin{array}{r}3 \\
6 \\
1 \\
1 \\
1 \\
1 \\
1 \\
50\end{array}$ & $\begin{array}{l}5.40^{* *} \\
1.64 \\
0.46 \\
1.08 \\
5.13 * \\
0.02 \\
0.61 \\
0.80\end{array}$ & $\begin{array}{l}4.00^{* *} \\
0.12 \\
0.12 \\
0.38 \\
0.00 \\
0.00 \\
0.11 \\
0.67\end{array}$ & $\begin{array}{l}4.27 \\
0.27 \\
0.21 \\
0.00 \\
0.45 \\
0.04 \\
0.03 \\
0.87\end{array}$ & $\begin{array}{l}0.047^{*} * \\
0.013^{*} \\
0.013 \\
0.025^{*} \\
0.032^{*} \\
0.000 \\
0.002 \\
0.005\end{array}$ & $\begin{array}{l}0.057^{* *} \\
0.003 \\
0.004 \\
0.001 \\
0.005 \\
0.000 \\
0.009 \\
0.005\end{array}$ & $\begin{array}{l}0.051 * \\
0.010 \\
0.000 \\
0.002 \\
0.001 \\
0.003 \\
0.023 \\
0.006\end{array}$ \\
\hline
\end{tabular}

**, Significant at the 0.01 and 0.05 probability levels, respectively.

$+\mathrm{CC}=$ continuous com, CSB = continuous soybean, CSG = continuous grain sorghum, C-SB = corn-soybean, SG-SB = grain sorghum-soybean, $\mathrm{C}-\mathrm{OCL}-\mathrm{SG}-\mathrm{SB}$ = corn-oat + clover-grain sorghum-soybean, C-SB-SG-OCL = corn-soybean-grain sorghum-oat +clover.

$\ddagger$ Change in $C$ and $N$ concentrations from 1984 to 1992 .

8 Depth, cm.

1 Contrasts.

The amount of $\mathrm{C}$ and $\mathrm{N}$ sequestered or lost essentially reflects the above changes in total soil $\mathrm{C}$ and $\mathrm{N}$ concentrations, except that now it represents changes in the tilled zone under each of these management systems. Based on these data, our results indicate that it is actually possible, by utilizing good management practices, to maintain and in many cases to improve soils in the western Corn Belt and similar areas of the USA, because of $\mathrm{C}$ and $\mathrm{N}$ sequestering into the soil organic matter.
Our results indicate that selection of cropping system and the level of $\mathrm{N}$ fertilization can greatly affect $\mathrm{CO}_{2}$ emissions, even to a much greater extent than proposed in a recent report (CAST, 1992). In that report, it was calculated that soil $\mathrm{C}$ levels would be increased by 0.1 to $0.3 \mathrm{~kg} \mathrm{~m}^{-2}$ in the next $40 \mathrm{yr}$ if high-yielding varieties, $\mathrm{N}$ and $\mathrm{P}$ fertilizers, no straw removal, and minimum tillage practices were adapted autonomously. Our results indicate that soil $\mathrm{C}$ levels may be increased to an even greater 
Table 5. Change in total soil $C$ and $N$ concentrations with a high rate of $N$ applied from 1984 to 1992 in each rotation at the $0-$ to 7.5 -cm, 7.5- to $15-\mathrm{cm}$, and 15- to 30-cm depths at Mead, NE.

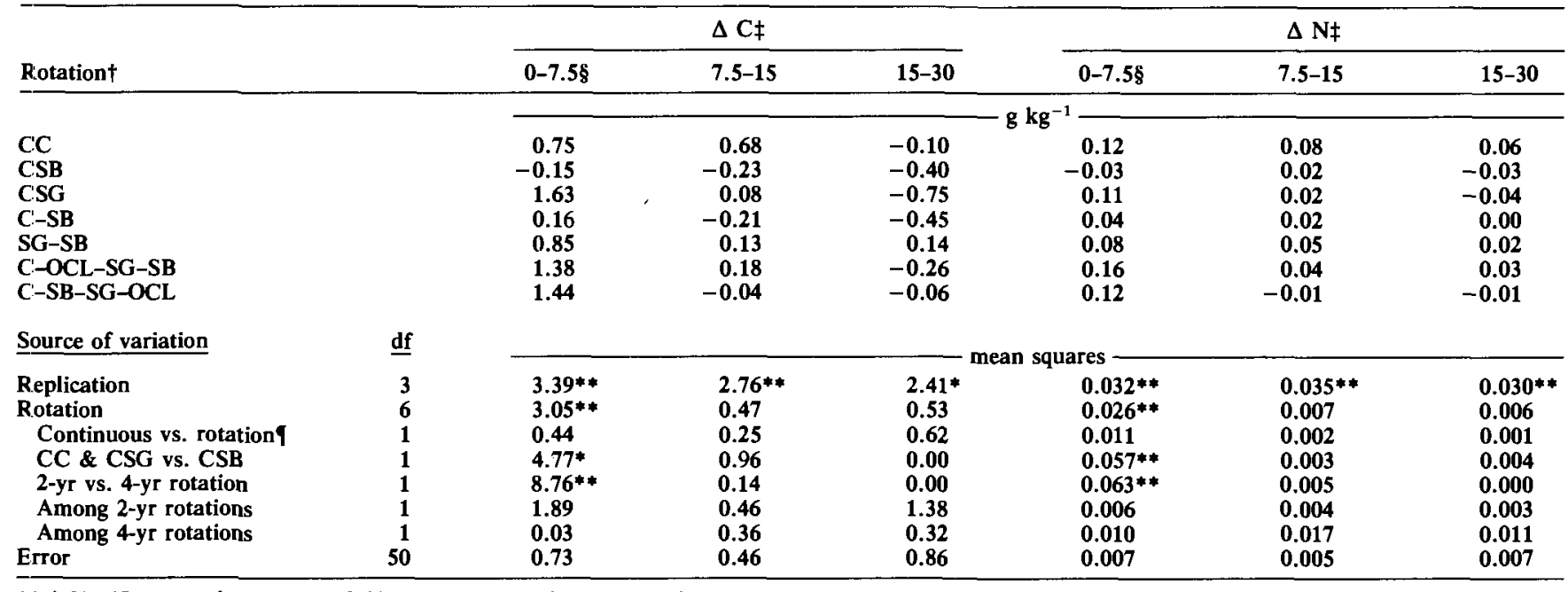

**** Significant at the 0.01 and 0.05 probability levels, respectively.

$+\mathrm{CC}=$ continuous corn, CSB = continuous soybean, CSG = continuous grain sorghum, C-SB = corn-soybean, SG-SB = grain sorghum-soybean, C-OCL-SG-SB = corn-oat + clover-grain sorghum-soybean, C-SB-SG-OCL = corn-soybean-grain sorghum-oat + clover .

¥ Change in $C$ and $N$ concentrations from 1984 to 1992 .

$\$$ Depth, cm.

1 Contrasts.

Table 6. Total soil $\mathrm{C}$ and $\mathrm{N}$ sequestered in each rotation at the 0 , low, and high $\mathbf{N}$ fertilizer rates for the $0-$ to $15-\mathrm{cm}$ depth from 1984 through 1992 at Mead, NE.

\begin{tabular}{|c|c|c|c|c|c|c|}
\hline \multirow[b]{2}{*}{ Rotation $\dagger$} & \multicolumn{3}{|c|}{ C sequestered $\ddagger$} & \multicolumn{3}{|c|}{ N sequestered $\ddagger$} \\
\hline & $0 \S$ & Low & High & $0 \$$ & Low & High \\
\hline & \multicolumn{6}{|c|}{$\longrightarrow \mathrm{kg} \mathrm{ha}^{-1} 8 \mathrm{yr}^{-1}$} \\
\hline $\mathrm{CC}$ & -534 & 186 & 1358 & 14 & 111 & 189 \\
\hline CSB & -855 & -203 & -363 & -56 & -4 & -14 \\
\hline CSG & 259 & 1316 & 1538 & -19 & 85 & 117 \\
\hline C-SB & -283 & 186 & -69 & 17 & 55 & 57 \\
\hline SG-SB & 333 & 228 & 892 & 74 & 71 & 124 \\
\hline C-OCL-SG-SB & 870 & 644 & 1420 & 114 & 114 & 177 \\
\hline C-SB-SG-OCL & 454 & 1012 & 1261 & 12 & 67 & 99 \\
\hline
\end{tabular}

$+\mathrm{CC}=$ continuous corn, $\mathrm{CSB}=$ continuous soybean, $\mathrm{CSG}=$ continuous grain sorghum, C-SB = corn-soybean, SG-SB = grain sorghum-soybean, C-OCL-SG-SB = corn-oat + clover-grain sorghum-soybean, C-SB-SGOCL = corn-soybean-grain sorghum-oat + clover.

$\ddagger$ At the 0 - to $15-\mathrm{cm}$ depth.

$\S \mathrm{N}$ fertilizer rate, $\mathrm{kg} \mathrm{ha}^{-1}$.

extent than this by selecting certain crop rotations. Soil $C$ levels were increased at rates up to $19 \mathrm{~g} \mathrm{~m}^{-2} \mathrm{yr}^{-1}$ in selected cropping systems at high $\mathbf{N}$ fertilizer rates with conventional tillage systems. It appears that it is not only the amount of crop residue being returned to the soil that is important, but also the amount and type of crop residue. Greater storage of $\mathrm{C}$ in soils with these practices suggests $\mathrm{CO}_{2}$ emissions from agricultural soils could be decreased and may in the long term have a significant effect on $\mathrm{CO}_{2}$ in the atmosphere under current climate conditions.

\section{REFERENCES}

Bauer, A., and A.L. Black. 1981. Soil carbon, nitrogen, and bulk density comparisons in two cropland tillage systems after 25 years and in virgin grassland. Soil Sci. Soc. Am. J. 45:1166-1170.

Blevins, R.L., G.W. Thomas, M.S. Smith, W.W. Frye, and P.L. Cornelius. 1983. Changes in soil properties after 10 years of continuous non-tilled and conventionally tilled corn. Soil Tillage Res. 3:135-136.
Council for Agricultural Science and Technology. 1992. Preparing U.S. agriculture for global climate change. Task Force Report no. 119. CAST, Ames, IA.

Dalal, R.C., and R.J. Mayer. 1986. Long-term trends in fertility of soils under continuous cultivation and cereal cropping in southern Queensland: I. Overall changes in soil properties and trends in winter cereal yields. Aust. J. Soil Res. 24:265-279.

Dick, W.A., D.M. Van Doren, Jr., G.B. Triplett, Jr., and J.E. Henry. 1986a. Influence of long-term tillage and rotation combinations on crop yields and selected soil parameters: I. Results obtained for a Mollic Ochraqualf soil. Res. Bull. 1180. Ohio Agric. Res. and Dev. Ctr., Ohio State Univ., Wooster, OH.

Dick, W.A., D.M. Van Doren, Jr., G.B. Triplett, Jr., and J.E. Henry. 1986b. Influence of long-term tillage and rotation combinations on crop yields and selected soil parameters: II. Results obtained for a Typic Fragiudalf soil. Res. Bull. 1181. Ohio Agric. Res. and Dev. Ctr., Ohio State Univ., Wooster, OH.

Doran, J.W. , and T.B. Parkin. 1994. Defining and assessing soil quality. In J.W. Doran et al. (ed.) Defining soil quality for a sustainable environment. SSSA Spec. Publ. 35. ASA and SSSA, Madison, WI (in press).

Gallaher, R.N., and M.A. Ferrer. 1987. Effect of no-tillage vs. conventional tillage on soil organic matter and nitrogen contents. Commun. Soil Sci. Plant Anal. 18:1061-1076.

Haas, H.J., C.E. Evans, and E.F. Miles. 1957. Nitrogen and carbon changes in Great Plains soils as influenced by cropping and soil treatments. USDA Tech. Bull. 1164. U.S. Gov. Print. Office, Washington, DC.

Hargrove, W.L., and W.W. Frye. 1987. The need for legume cover crops in conservation tillage production. p. 1-4. In J.F. Power (ed.) The role of legumes in conservation tillage systems. Soil Conserv. Soc. Am., Ankeny, IA.

Havlin, J.L., D.E. Kissel, L.D. Maddux, M.M. Claasen, and J.H. Long. 1990. Crop rotation and tillage effects on soil organic carbon and nitrogen. Soil Sci. Soc. Am. J. 54:448-452.

Johnston, A.E. 1986. Soil organic matter, effects on soil and crops. Soil Use Manage. 2:97-105.

Lamb, J.A., G.A. Peterson, and C.R. Fenster. 1985. Wheat fallow tillage systems' effect on a newly cultivated grassland soils' nitrogen budget. Soil Sci. Soc. Am. J. 49:352-356.

Larson, W.E., C.E. Clapp, W.H. Pierre, and Y.B. Morachan. 1972. Effects of increasing amounts of organic residues on continuous corn: II. Organic carbon, nitrogen, phosphorus, and sulfur. Agron. J. 64:204-208. 
Larson, W.E., R.F. Holt, and C.W. Carlson. 1978. Residues for soil conservation. p. 1-15. In W.R. Oschwald (ed.) Crop residue management systems. ASA Spec. Publ. 31. ASA, CSSA, and SSSA, Madison, WI.

Odell, R.T., Melsted, S.W., and W.M. Walker. 1984. Changes in organic carbon and nitrogen of Morrow Plot soils under different treatments, 1904-1973. Soil Sci. 137:160-171.

Power, J.F., and J.O. Legg. 1978. Effect of crop residues on the soil chemical environment and nutrient availability. p. 85-100. In W.R. Oschwald (ed.) Crop residue management systems. ASA Spec. Publ. 31. ASA, CSSA, and SSSA, Madison, WI.

Rasmussen, P.E., R.R. Allmaras, C.R. Rhode, and N.C. Roager. 1980. Crop residue influences on soil carbon and nitrogen in a wheat-fallow system. Soil Sci. Soc. Am. J. 44:596-600.

SAS Institute. 1992. SAS/STAT User's Guide. 4th ed. SAS Inst., Cary, NC.
Schepers, J.S., D.D. Francis, and M.T. Thompson. 1989. Simultaneous determination of total $\mathrm{C}$, total $\mathrm{N}$, and ${ }^{15} \mathrm{~N}$ on soil and plant material. Commun. Soil Sci. Plant Anal. 20:949-959.

Steel, R.G.D., and J.H. Torrie. 1980. Principles and procedures of statistics: A biometrical approach. 2nd ed. McGraw-Hill Book Co., New York.

Stevenson, F.J. 1986. Cycles of soil: Carbon, nitrogen, phosphorus, sulfur, and micronutrients. John Wiley \& Sons, New York.

Tate, R.L. 1987. Soil organic matter: Biological and ecological effects. John Wiley \& Sons, New York.

Tiessen, H., J.W.B. Stewart, and J.R. Bettany. 1982. Cultivation effects on the amounts and concentration of carbon, nitrogen, and phosphorus in grassland soils. Agron. J. 74:831-835.

U.S. Environmental Protection Agency. 1991. The impact of conservation tillage use on soil and atmospheric carbon in the contiguous United States. EPA/600/3-91/056. USEPA, Washington, DC. 